\title{
Debat
}

\section{Immobile og uvillige geologer - eller tid til at nytoenke uddannelsen?}

Af geologerne Ole Christensen, Norge, Søren M. Kristiansen, Arhus, og Thomas Varming, Farøerne

Vi foreslår at bruge den nuværende krise med få nye studerende, manglende jobs til nyuddannede, og mange ældre ansatte på universiteter og $\mathrm{i}$ industrien til at nytænke hele den faggeologiske uddannelse i Danmark. Det skal ske med baggrund i viden om, hvordan Jorden kan gavne samfundets udvikling, så færdiguddannede kandidater får større jobchancer. Og det under navnet Geovidenskab i stedet for Geologi, så "støvet" samtidig bliver rystet af!

I GeologiskNyt 1/04 blev der stillet skarpt på manglende jobs for færdiguddannede geologer og en statsfinansieret isbryderordning. Man kan dog med rimelighed spørge, hvorfor der skal bruges flere offentlige midler på at omskole allerede dyrt uddannede akademikere som os geologer. Er det, fordi vi får en utidssvarende uddannelse, som ikke direkte kan bruges af erhvervslivet og i den offentlige administration? Eller er det fordi vi danske geologer er immobile og uvillige? Vi mener faktisk, at begge spørgsmål kan besvares med et JA!

\section{Derfor JA}

"'Ja" til en utidssvarende uddannelse støttes af undersøgelserne i GeologiskNyt 4/01. De viser, at 3 ud af 4 geologistuderende føler, de ikke får en erhvervsrelevant uddannelse, samt at arbejdsløsheden er stor de første år. Men samtidig viser PESGB's (Petroleum Exploration Society of Great Britain) statistikker både mange ældre ansatte og en global mangel på geologer i oliebranchen - også nyuddannede lige fra universitet.

Svaret er nok et "delvist ja" til de immobile og uvillige geologer. "Ja", fordi vi ser arbejdsløse geologer koncentreret i Århus og København, mens visse engelske oliefirmaer mangler kvalificeret arbejdskraft. "Delvist" fordi selvom den unge geolog er både mobil og villig, kan han/hun jo let være uegnet, hvis de ledige stillinger er inden for områder, han/hun ikke har specialiseret sig i.
Så hvis geologi på danske universiteter skal fremstå som en attraktiv karrierevej for unge mennesker anno 2004 og en attraktiv uddannelse for arbejdsgiverne, bør der ske radikale ændringer. For vi tror på, at der også i fremtidens videnssamfund er brug for mange og veluddannede geologer-der også er villige til at flytte efter job.

\section{Studiet i dag}

På at skrive sit speciale eller ph.d. bruger de studerende gerne meget længere tid end normeret. 7-8 år er således ikke usædvanligt før kandidateksamen. Dette er ikke alene en personlig, økonomisk katastrofe, men det gør også den nyuddannede mindre interessant for erhvervslivet. Man fremstår som en akademiker, der ikke kan holde en tidsplan, og samtidig bindes han/hun unødvendigt til uddannelsesbyen, hvor konkurrencen om jobbene er ekstra hård.

Sammenligner man ydermere antallet af nye studenter de senere år med antallet af professorer og lektorer, ses det, at hver nyoptaget geologstuderende på Aarhus og København Universitet har ca. 2 videnskabeligt ansatte til rådighed. Men stadigvæk tager det ekstra tid af få folk igennem til cand.scient.-graden. Og herefter venter mange i flere år, før de kan blive omskolet, så geologien kan blive reduceret til en fritidsinteresse, eller de kan få et ph.d.-stipendium. Dette finder vi påfaldende, når man ser på Norge og Sverige, hvor hver videnskabeligt ansat har op mod 20 studerende, som bliver færdige til tiden og får relevante jobs.

Antallet af studerende er de seneste år også reduceret til et historisk lavt niveau. Således er der i 2003 kun optaget omkring $20 \mathrm{i}$ både Århus og København. Hvad grunden hertil er, er os bekendt usikkert - men til dels forbundet med undervisningen i folkeskolen og gymnasiet. Men inden de ansvarlige i uddannelsesmiljøet stirrer sig blinde på den manglende rekruttering, bør man starte med en vis selvransagelse. For det er ingen naturlov, at 30-40\% skal falde fra en uddannelse, inden yderligere en større del af de færdiguddannede må omskoles til en anden branche!

\section{Geologiuddannelsen}

Vi mener, problemerne med dårligt kvalificerede nyuddannede opstår pga. et umoderne uddannelsessystem, hvor man i Danmark har opbygget samme uddannelse på flere

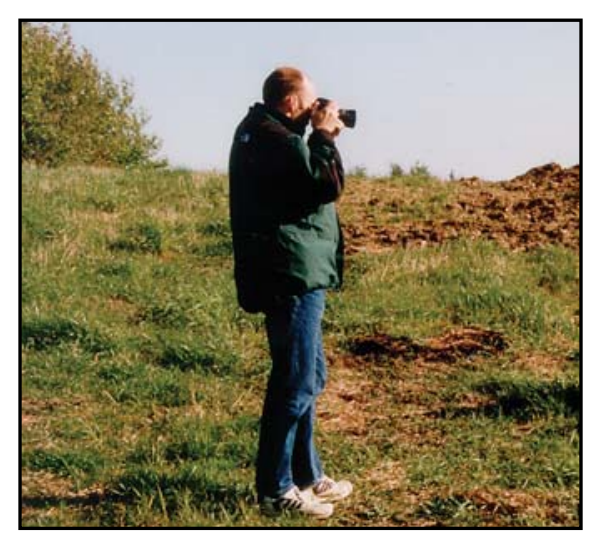

Hvad skal der fokuseres på i fremtiden? (Foto: Steen Laursen, GeologiskNyt)

universiteter trods landets lidenhed. Det betyder, at man i dag med under 50 kandidater per år inden for geovidenskaberne/ Earth Sciences (geologi, geofysik, dele af geografi) har dem spredt på adskillige institutioner i København, Århus og Ålborg. Universiteterne forsvarer dette med næb og klør med påstand om, at konkurrence skaber bedre studier. Det, mener vi, er en fejl. Fx oplever vi, at danske studerende sjældent flytter imellem danske universiteter, men derimod søger udenlandske universiteter eller private firmaer for at afslutte eller forbedre deres uddannelse.

Universiteterne bør ikke bare forbedre uddannelsen, men bør også etablere kontakt og følge deres kandidater ind i jobmarkedet. Det kan givetvis ikke ske fra centralt hold, men fra de enkle vejledere. I øjeblikket belønnes afdelinger for hver kandidat eller ph.d.-eksamen, men det, mener vi, er en fejl. Vejledningen er først færdig, når studenten har fået et relevant job og bør først belønnes herefter. Især da arbejdsformidlingssystemet ikke kan hjælpe højtuddannede eksperter - det kan kun folk, der kender til miljøet. Dog tror vi ikke, at det kan ske med den store geografiske spredning af den geologiske viden.

\section{Et samlet uddannelsesmiljø}

Fagmiljøet omkring det nyligt oprettede Geocenter i København, kan man håbe, giver en stor faglig brede og tyngde til forskningen. Men vi mener ikke, at sammenlægningen løser problemet med manglende relevans i studietiden og manglende job efter studiet.

Vi foreslår, at en bedre - men mere radikal-løsning er at samle det geologiske/geovidenskabelige uddannelsesmiljøi Danmark 
på et sted. Formålet med en sådan sammenlægning er først og fremmest at uddanne de studerende til at varetage et job umiddelbart efter universitetet. Flere af forfatterne nyder fx godt af at befinde sig på sådanne kompetencecentre, som er blevet skabt ved sammenlægning og forflytning af forskere til et nyt miljø.

Et sådant "Dansk Center for Geovidenskaber" kunne måske endda placeres uden for de nuværende universitetsbyer? Det er for eksempel oplagt at lægge et geovidenskabeligt center i Esbjerg. Det er ikke alene Danmarks olieby nummer et, men det ligger også ved Vadehavet og Nordsøen med de mange aktive geologiske processer.

Fordelen ved en sådan flytning er billigere drift, samt at det gør de studerende og ansatte bevidste om, at geologi ikke findes $i$ storbyen.

\section{Undervisning i verdensklasse}

For at skabe en internationalt orienteret geovidenskabelig uddannelse må staben bestå af internationalt anerkendte forskere og ikke kun de bedste danske. Det synes nok trivielt at nævne, men de skal efter vores opfattelse ikke alene være fagligt dygtige, men skal også formå at vejlede de studerende, så de får en reel jobmulighed og bliver færdige på normeret tid.

De ansattes kvalitet bør derfor ikke alene måles på deres forskningsindsats og antal af rettidigt færdige kandidater, men $i$ lige så høj grad på procentdelen der finder relevant arbejde efter studiet. Dette kræver faktisk også at underviserne har et nationalt, internationalt og ikke mindst erhvervsrelateret netværk.

Danske ph.d.-stipendiater forsker ofte i et emne efter eget valg. I vore nabolande opslås ph.d.-stipendier ofte $i$ et samarbejde mellem industri og det offentlige, så forskningen har et formål udover at uddanne endnu en dygtig ph.d. Hvad om danske universitetsvejledere og dermed -forskere, gjorde dette oftere af egen drift? Vi er bevidste om, at dette er store krav at stille. Men omvendt hvorfor må man i dag ikke stille større krav til universitetsansatte for- skere/undervisere end for 30-40 år siden? Vi ser denne udvikling i samfundet som helhed, så hvorfor ikke også universitetet?

\section{Hvad kan vi tilbyde arbejdsgiverne?}

Fra tal fra den nærmest beslægtede branche for langt hovedparten af os, nemlig ingeniørernes, ved vi, at danske arbejdsgivere har ønsker til de færdiguddannede. Fx ønskes folk med brede baggrunde, samarbejdsevner og med specialisering (se fx Ingeniøren $\mathrm{nr}$. 12, 2004). Men hvad er kravene til kandidater og bachelorer i geologi?

Udviklingen i olieindustrien er blevet sammenlignet med den, man havde i ITbranchen for nogle år tilbage. Tidligere ville man bare have folk, som kendte noget til en computer, i dag vil man have mere specialiserede folk. Det, som vi hører, at oliefirmaerne efterspørger, er da heller ikke nyudklækkede studerende, men folk med lidt erfaring og gerne med specialiseret viden inden for et område. Men dem er der ikke mange af.

Hvad om universiteterne iværksatte undersøgelser vedr. arbejdsgivernes ønsker i forhold til antal og kvalifikationer af nyansatte geologer? Vil virksomhederne og den offentlige administration kun have folk med brede faglige kvalifikationer, eller ønsker de derimod fagspecialister. Hvis det, som hos ingeniørerne er begge dele, der ønskes, så mener vi, at bachelor- og kandidatuddannelserne bør indrettes bedre hertil. Dette kan sandsynligvis modvirke, at fremtidens kandidater skal omskoles, inden de kan få et job. I denne forbindelse er vi ikke bange for, at man vil "tabe" de studerende, som vil gøre karriere inden for forskningen. For erhvervs- og forskningsrelevans kan udmærket kombineres.

\section{Jobmulighederne}

Selvom de unge geologer er villige til at flytte til udlandet, er den internationale konkurrence hård. Fx skal danske kandidater konkurrere med 25-årige ph.d.-ere fra Storbritannien, som kun har brugt 6-7 år på universitetet. Ofte med et studium der delvist er betalt af og udført sammen med de firmaer, der senere efterspørger deres arbejdskraft.

Undersøgelser i GN 4/01 viste da også, at mange nyuddannede geologer har svært ved at få arbejde. Således havde to årgange fra 1990erne en arbejdsløshed på $36 \%$ det første år efter kandidateksamen, som faldt til $7 \%$ efter to-tre år. Primært pga. at 30-40 $\%$ fik ikke-geologisk relevante ansættelser. Og det $\mathrm{i}$ en periode hvor arbejdsløsheden $\mathrm{i}$ samfundet var historiske lav.

Men er det svært at få arbejde, eller er det kun et problem for bestemte grupper af nyuddannede? Der findes tilsyneladende ingen statistik, der belyser specialevalg på universiteterne og den efterfølgende karriere. Vores personlige erfaringer er dog, at de nyuddannede geologer, som ikke får et fagrelevant job, primært har bestemte specialer på universitet. Så vi spørger derfor, om det frie specialevalg fortsat er vejen frem?

Et faktum, der givetvis bør indgå i denne diskussion, er, at dinosaurer og vulkaner af naturlige årsager ikke findes i Danmark, og at hårde bjergarter kun findes i de nordlige dele af rigsfællesskabet. Vi i syd er derimod rige på olie, grundvand og løse sedimenter. Så det er vel naivt at tro, at alle, der i studiet specialisere sig i førstnævnte felter, kan få arbejde i Danmark uden for forskningen?

\section{Hvad nu?}

Vores råd til de geologistuderende i dag er derfor: Se dit speciale som vejen til jobbet. Fx sponsorerer flere virksomheder specialestuderende for at arbejde på et problem, så man går uden om et indgroet system og får relevante problemer at arbejde med. Specialiseringen er et valg, som DU selv er ansvarlig for, og som enten kan starte eller slutte karrieren! Så vælg med omhu - og husk at vulkaner og dinosaurer ikke findes i dagens Danmark.

Og til de ansvarlige på de "gamle" geologiske institutter: Nytænk den geologiske uddannelse i Danmark i et større perspektiv, før der udefra kommer et pres for et mere afsætningsorienteret studium fra de nye universitetsbestyrelser eller fra fremtidige institutledere med ekstern baggrund. 